\title{
EFFECTS OF DIFFERENT FERTILIZER DOSES ON THE YIELD AND SOME QUALITY PARAMETERS OF WINTER WHEAT
}

\author{
Péter Jakab, Nóra Masa, Anita Baranyi, Margit Szél Hódiné \\ University of Szeged, Faculty of Agriculture, Hódmezővásárhely, Hungary \\ jakab.peter@mgk.u-szeged.hu
}

\begin{abstract}
The influence of different fertilizer doses on the yield and quality of winter wheat was studied on meadow soil in the crop-year 2016-2017 in Hódmezővásárhely. The experiment was set up on the area of the SZTE Tangazdaság Ltd, in three replications. The forecrop was sunflower. Six fertilizer setups were applied besides the control: N80PK30, N100PK30, N130PK30, N150PK30, N170PK0, and N170PK50 kg/ha active ingredients. The year 2016-2017 was unfavourable for winter wheat production. The amount of precipitation in the vegetative period of winter wheat was lower than the average. The obtained data were processed by single factor ANOVA. In the control treatment, the yield was $4.20 \mathrm{t} / \mathrm{ha}$. The maximum yield of $5.60 \mathrm{t} / \mathrm{ha}$ was reached with N130PK30 kg/ha fertilizer treatment. The yield difference between the two treatments was statistically justified. The nutrient doses higher than N130PK30 did not increase the yield of wheat.

A crude protein content of $17.60 \%$ was measured in the N0PK0 treatment. The highest content of crude protein $(18.70 \%)$ was in the N100PK30 and N130PK30 treatments. The Zeleny number was $70.40 \mathrm{ml}$ in the control treatment. In the N130PK30 treatment, it reached the maximum value of $76.0 \mathrm{ml}$. In our experiment, the $\mathrm{N} 130 \mathrm{PK} 30 \mathrm{~kg} / \mathrm{ha}$ fertilizer dose was the most favourable concerning the yield and quality parameters of the examined winter wheat variety.
\end{abstract}

Keywords: winter wheat, fertilization, yield, gluten content, crude protein content

\section{INTRODUCTION}

Cereals are the most important field crops in Hungary and also all over the world. Winter wheat has specific importance on most parts of the Earth, because its production is possible even in case of extreme soil and ecological conditions due to its extraordinary adapting ability (ZSOMBIK AND ERDŐS, 2014; SZILÁGYI, 2016).

The nutrient supply is only one of several factors of utilizing the genetic potential of wheat varieties (KRISTÓ ET AL., 2008; CZIMBALMOS ET AL., 2014, 2016).

Providing a balanced nutrient supply is essential, since it has a remarkable effect on the quality and the quantity of the yield, on the environment, and also on the effectiveness of production. (SÁRVÁRI, 1984; JAKAB ET AL., 2016; JAKAB ET AL., 2017).

The crop-year basically determined the dry matter production, assimilation area and yield of winter wheat; these effects were modified by fertilization. The effects of genotypes were moderated (PEPÓ, 2005).

The lower amount of winter wheat yields on average might have been caused by applying lower amounts of fertilisers. Consequently, fertilisation must be increased to have higher crop averages (KOMAREK, 2007, 2008).

Today the number of farmers using various soil bacterium preparations in addition to chemical fertilisation is growing.

There are different types of bacteria in these preparations, which can improve the nutrient supply of plant. When applying these products the amount of chemicals can be reduced and in this way we contribute to an environmentally friendly and economical production. The products improve the physical and chemical properties of the soil and maintain soil fertility. (MÁRTON AND DAODA, 2001; ÁRVAY, 2004; BíRÓ, 2004; JAKAB ET AL., 2004; JAKAB, 2006a; JAKAB, 2006b; JAKAB, 2010). 
The environmental components have great effect on the quality of winter wheat, but the wheats of different genotypes react differently to the environmental effects (PETERSON ET AL., 1998; KUTASY ET AL., 2005).

The yield and quality fluctuation between the years can be reduced by applying good varieties and professional agro-technical methods (KUTASY ÉS CSAJBÓK, 2001; GYÖRI, 2006; KRISTÓ ET AL., 2007; PEPÓ AND CSAJBÓK, 2014; ZsOMBIK AND SERES, 2018).

TANÁCS ET AL. (2000) studied the effect of fungicides and foliar fertilizers on the quality of winter wheat. They stated that the variety $\mathrm{x}$ fungicide treatments caused significant changes in the examined quality parameters (gluten content, falling number), but the effect of foliar fertilizers was lower.

In a dry year, the effect of fungicide treatments was not significant for the baking industry parameters such as wet and dry gluten content, and falling number (TANÁCS AND GERÖ, 2002).

TANÁCS ET AL. (1997) examined the effect of NPK fertilization on the amino acid composition of winter wheat grain yield. They found that the highest amino acid value was in N $180 \mathrm{~kg}$ /ha fertilizer dosage except for the ARG and HIS.

The fertilization had positive effect on the baking parameters of winter wheat. Among the macro-elements, the nitrogen had the highest effect on the quality parameters of winter wheat (JolÁnKai ET AL., 1990; RAgASITS AND SZABÓ, 1992; TANÁCS ET AL., 1993, TANÁCS, 2005).

\section{MATERIAL AND METHOD}

The experiment was carried out in three replications on the area of SZTE Tangazdaság Ltd. The soil was meadow soil. The soil analysis data showed, that it had good nitrogen and very good phosphorus and potassium content (Table 1).

Table 1. Main properties of the experimental field area

\begin{tabular}{|c|c|c|c|c|}
\hline $\begin{array}{c}\mathbf{p H} \\
\mathbf{K C L})\end{array}$ & $\begin{array}{c}\mathbf{P}_{\mathbf{2}} \mathbf{O}_{\mathbf{5}} \\
(\mathbf{m g} / \mathbf{k g})\end{array}$ & $\begin{array}{c}\mathbf{K}_{\mathbf{2}} \mathbf{O} \\
(\mathbf{m g} / \mathbf{k g})\end{array}$ & $\begin{array}{c}\text { Humus } \\
\mathbf{( \% )}\end{array}$ & $\begin{array}{c}\text { Soil plasticity } \\
\text { value }\left(\mathbf{K}_{\mathbf{A}}\right)\end{array}$ \\
\hline 7.16 & 335 & 619 & 3.38 & 48 \\
\hline
\end{tabular}

Source: HL-LAB Ltd., 2016

The year 2016-2017 was unfavourable for winter wheat production. The amount of precipitation in the vegetative period of winter wheat was lower than the average. The distribution of precipitation was unfavourable. The rainfall in November, April and May was more than the average, while in December, January, February, March, and June less rain fell compared to the average (Table 2).

Table 2. The distribution of precipitation in the vegetative period of winter wheat in 2016-2017

\begin{tabular}{|c||c||c|c|}
\hline Month & Rainfall $\mathbf{( m m )}$ & $\begin{array}{c}\text { 50 years average } \\
\text { rainfall } \\
\mathbf{( m m}\end{array}$ & $\begin{array}{c}\text { Difference } \\
\mathbf{( m m})\end{array}$ \\
\hline \hline October & 88.0 & 34.7 & 53.3 \\
\hline November & 50.0 & 41.1 & 8.9 \\
\hline December & 2.0 & 43.0 & -41.0 \\
\hline January & 20.0 & 30.6 & -10.6 \\
\hline February & 24.0 & 30.1 & -6.1 \\
\hline March & 11.0 & 29.8 & -18.8 \\
\hline
\end{tabular}




\begin{tabular}{|c||c||c||c|}
\hline April & 43.0 & 39.9 & 3.1 \\
\hline May & 71.0 & 58.0 & 13.0 \\
\hline June & 48.0 & 75.3 & -27.3 \\
\hline July & 4.0 & 58.7 & -54.7 \\
\hline \hline $\begin{array}{c}\text { Total amount of } \\
\text { rainfall (mm) }\end{array}$ & $\mathbf{3 6 1 . 0}$ & $\mathbf{4 4 1 . 0}$ & $\mathbf{- 8 0 . 2}$ \\
\hline
\end{tabular}

Source: SZTE Tangazdaság Ltd.

The small-scale plough experiment was set in three replications, organised as a random block in 2016. Beside the control, we applied six fertilizer treatments: N80PK30, N100PK30, N130PK30, N150PK30, N170PK0, and N170PK50 kg/ha active ingredients. The forecrop was sunflower. The variety was Lucullus. We processed the obtained data by single factor ANOVA.

\section{RESULTS}

In the control treatment, the yield was $4.2 \mathrm{t} / \mathrm{ha}$. Under the influence of fertilization, the yield increased (4.8-5.6 t/ha). We measured the maximum yield of 5.6 t/ha in N130PK30 treatment, which was significantly higher compared to the control. The higher fertilizer doses did not increase the yield compared to the N130PK30 dosage (Figure 1).

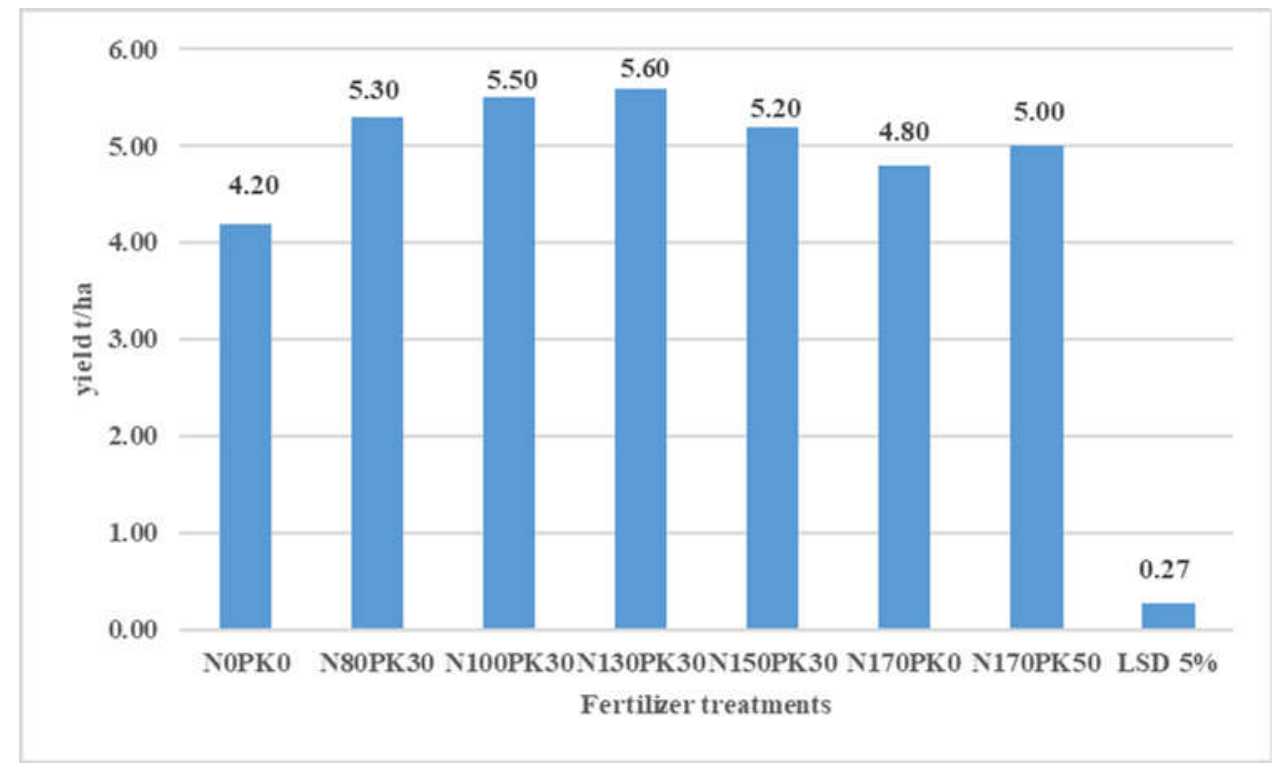

Figure 1. The effect of fertilization on the yield of winter wheat

We examined the effect of fertilization on the quality parameters (Zeleny number, crude protein content) of winter wheat. The Zeleny number in the control treatment was $70.4 \mathrm{ml}$. The maximum value was measured in the N130PK30 treatment, $76.0 \mathrm{ml}$. In the higher dose fertilizer treatments (N150PK30, N170PK0, N170PK50), we calculated less values (66.6-74.8 ml) compared to the N130PK30 treatment. Fertilization did not increase this quality parameter significantly (Figure 2). 


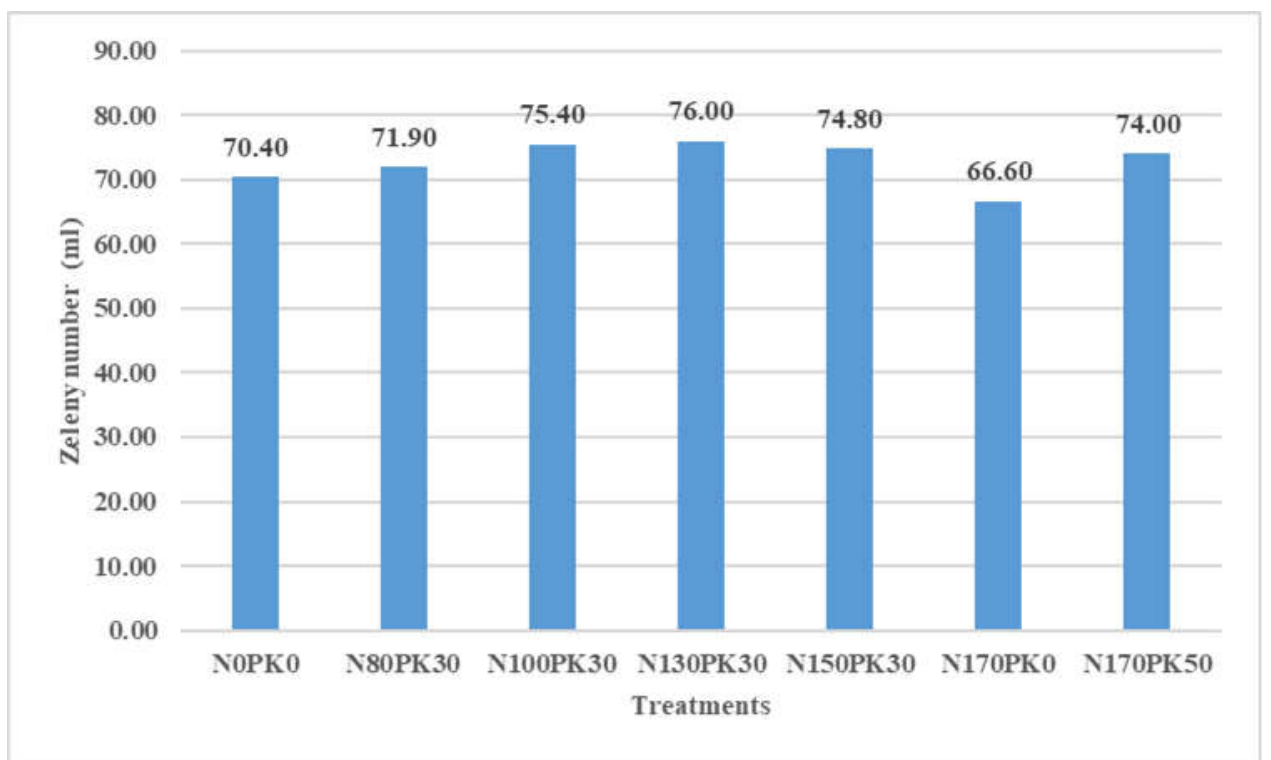

Figure 2. The effect of fertilization on the Zeleny number of winter wheat

The crude protein content of wheat grain was $17.6 \%$ in the control treatment. In most cases, we got higher results compared to the control, except for the N170PK0 treatment. The highest value was $18.7 \%$ in the N100PK30 and N130PK30 treatments. The increase was not significant compared to the control results (Figure 3).

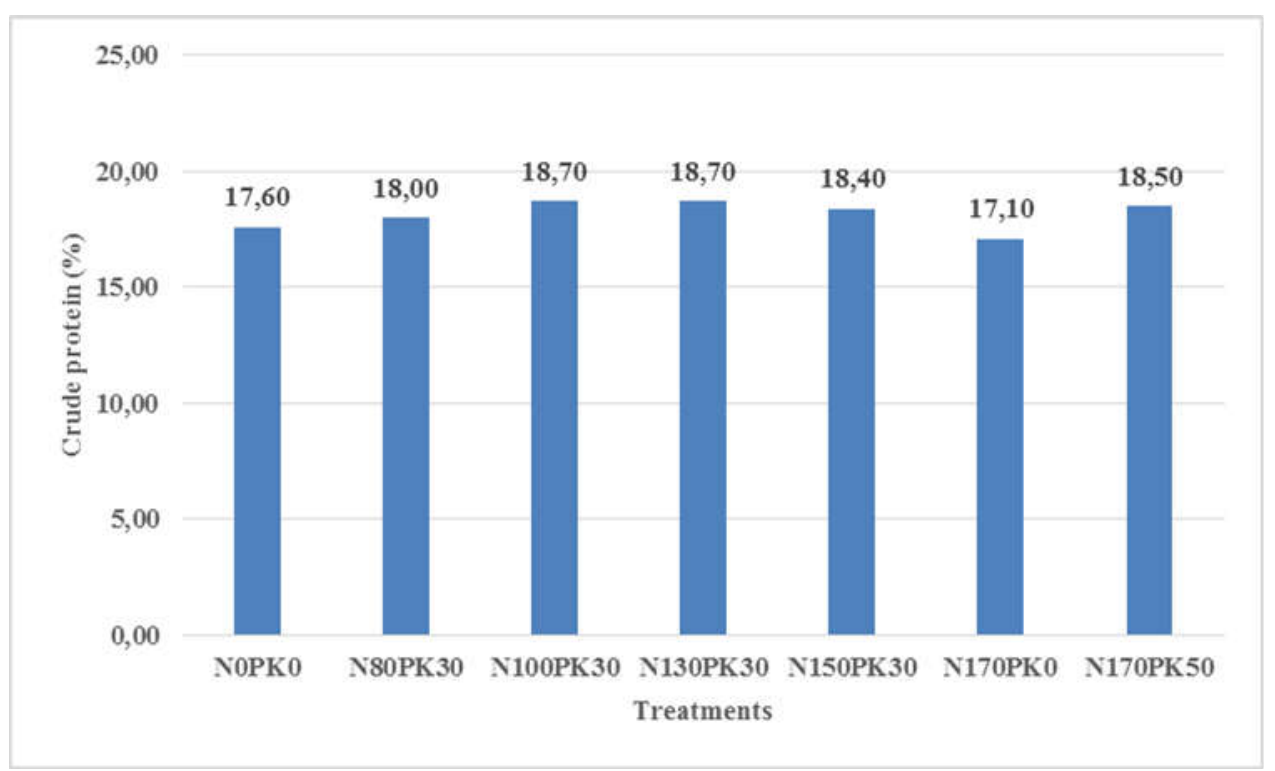

Figure 3. The effect of fertilization on the crude protein content of winter wheat

\section{CONCLUSIONS}

The year 2016-2017 was drier and warmer than the 50 years average. Therefore, the yield of the control plots was moderate: $4.2 \mathrm{t} / \mathrm{ha}$. Compared to this result, we measured higher results in fertilizer treatments. We got the highest yield of $5.60 \mathrm{t} / \mathrm{ha}$ in the N130PK30 fertilizer treatment. Fertilization had a positive effect on the quality parameters of winter wheat. The Zeleny number and crude protein content reached the maximum values in N130PK30 treatment, but the increase was not statistically justified. We can conclude that 
concerning the yield amount and the quality parameters of grain, the moderate fertilizer dosage of N130PK30 was the most favourable fertilizer dosage in our experiment.

\section{REFERENCES}

ÁRVAY, GY. (2004): Baktériumtrágyák. Mezőgazdasági tanácsok. 13. 10-12.

BíRÓ, B. (2004): Vegyük vagy ne vegyük? A baktériumtrágyák haszna és alkalmazási szempontjai. Mezőgazdasági tanácsok 13: 12-15.

Czimbalmos, Á., Jóvér, J., Zsembeli, J. (2014): Effects of fertilization on some quantitative and qualitative characteristics of winter wheat in Great Cumania. Columella: Journal of Agricultural and Environmental Sciences 1(1): 17-21.

CzIMBalmos, Á., szÜCS, L., Zsembeli, J. (2016): Karcagi nemesítésű őszi búzafajták (Triticum aestivum L.) tápanyag-reakciójának vizsgálata. Agrártudományi Közlemények 69: 63-67.

GYÖRI, Z. (2006): Ismét napirenden az öszi búza minősége. Gyakorlati Agrofórum 17(7): 27-28.

JAKAB, P. (2006a): A mütrágyázás és a talajbaktérium trágyázás hatása az őszi búza termésére és minőségére. In: XII. Ifjúsági Tudományos Fórum. Konferencia helye, ideje: Keszthely, Magyarország, 2006.04.20 PATE Georgikon Mezőgazdaságtudományi Kar, CD.

JAKAB, P. (2006b): Application of soil bacterium preparation in winter wheat production. In: Sz Hidvégi Sz. (ed.szerk.): Proceedings of the V. Alps-Adria Scientific Workshop. Cereal Research Communications Vol 34(No. 1). Konferencia helye, ideje: Opladen, Horvátország, 2006.03.06-2006.03.11. Budapest. Pp. 5-7.

JAKAB, P. (2010): Talajbaktérium készítmények alkalmazása a fenntartható növénytermesztésben. Összefoglaló. [In: Kóródi M. (edszerk.): Tudomány határok nélkül: Válságjelenségek összefüggései a gazdaságban és a társadalomban]. Szolnoki Főiskola, Szolnok. Pp. 99.

JAKAB, P., FESTŐ, D., KOMAREK, L. (2016): A mütrágyázás hatása az őszi búza termésére és termésképző elemeire. In: Futó Zoltán (szerk.) Kihívások a mai modern mezőgazdaságban. Konferencia helye, ideje: Szarvas, Magyarország, 2016.11.24 Szarvas. Szent István Egyetemi Kiadó. Pp. 68-73. (ISBN: 978-963-269-594-5)

P. JakaB, P., D. Festö, D., G. Zoltán, G., L. KomareK, L. (2017): Examination of fertilization of winter wheat on meadow chernozem soil. Research Journal of Agricultural Science 49(1): 127-134.

JAKAB, P., FutÓ, Z., LÉVAI, K., NAGY, P. (2004): A tápanyagellátás hatása az őszi búza fajták termésére. Összefoglaló. [In: Kalmár I. (ed.szerk.): IV. Alföldi Tudományos Tájgazdálkodási Napok]. Tessedik Sámuel Főiskola Mezőgazdasági Főiskolai Kar, Mezőtúr. Pp. 113.

JolÁNKAI, M., LőVEI, I., BALIKo, E. (1990): Agrotechnikai tényezők hatása a búza minőségére. Élelmezési Ipar 44: 125-127.

KOMAREK, L. (2007): A Dél-Alföldi Régió súlyának, szerepének alakulása a hazai agrártermelésben. Comitatus: Önkormányzati Szemle 17 (9): 52-64.

KomAREK, L. (2008): A Dél-Alföld agrárszerkezetének sajátosságai. Szeged: Csongrád Megyei Agrár Információs Szolgáltató és Oktatásszervező Kht, 143. (ISBN: 978-963-065325-1)

Kristó, I., Hegedüs, Sz., Petróczi, I., M. (2008): Investigation of the development of winter wheat under different fertilizer rates. Cereal Research Communications 36 (Suppl.): $1183-1186$. 
Kristó, I., Szarvas, A., Szarvas, M., Petróczi, I. M. (2007): A tápanyagellátás hatása az őszi búza fejlődésére. Agrár- és Vidékfejlesztési Szemle. 2(2): 111-117.

KUTASY E., CsAJBÓK, J. (2001): Ốszi búzafajták termésstabilitásának vizsgálata. Agrártudományi Közlemények 61-66.

KutAsy E., CsAJBÓK, J., Hunyadi Borbélyné É. (2005): Relations between yield and photosynthetic activity of winter wheat varieties. Cereal Research Communications 33: 173-176.

MÁRTON, J., DAODA, Z. (2001): Tápanyaggazdálkodás: az egészséges talajéletért. Innováció, a tudomány és a gyakorlat egysége az ezredforduló agráriumában. Gödöllő. 5861.

PEPÓ, P. (2005): Effect of crop year, genetic and agrotechnical factors on dry matter production and accumulation in winter wheat production. Cereal Research Communications 33(1): 29-32.

Pepó, P., CsAJBóK, J. (2014): Az agrotechnikai elemek szerepe az őszi búza (Triticum aestivum L.) termesztésében. Növénytermelés 63(3): 73-94.

Peterson, C.J., Graybosch, R.A., Shelton, D.R., Baenziger, P.S. (1998): Baking quality of hard winter wheat: response of cultivars to environment in the Great Plains. Euphytica 100.1/3.: 157-162.

Ragasits, M., Szabó, M. (1992): A búza minősége. In.: Bocz E. (ed.): Szántóföldi növénytermesztés. Budapest, Mezőgazdasági Kiadó, Budapest. 273-282.

SÁRVÁRI M. (1984): A vetésváltás és a tápanyagellátás hatása a búza és a kukorica termésére. Kandidátusi értekezés tézisei. Debrecen. University of Debrecen. 1-48. p.

SZILÁGYI, G. (2016): A vetésváltás és tápanyagellátás hatása őszibúza-genotípusok néhány fiziológiai, agronómiai tulajdonságára és termésére. Doktori (Ph.D.) értekezés. Debrecen. University of Debrecen. 1-185. p.

TANÁCS, L. (2005): Élelmiszer-ipari nyersanyagismeret. Szaktudás Kiadó Ház. Budapest. 1-396. .p. ISBN: 9639553476

TANÁCS, L., GERÖ, L. (2002): Fungiciddel kezelt két őszibúza-fajta sikértartalmának, terülésének és esésszámának alakulása. Növénytermelés 51(5): 497-507.

TANÁCS, L., MATUZ, J., BARTÓK, T., GERÖ, L. (1997): Az NPK-mütrágyázás hatása az őszi búza szemtermésének aminosav összetételére. Növénytermelés 46(1): 43-51.

TANÁCS, L., MatuZ, J., GerÖ, L., KovÁCS, K. (1993): Mütrágyázott őszi búzafajták sütőipari paramétereinek alakulása. Növénytermelés 42(6): 509-518.

TANÁCS, L., MATUZ, J., PETRÓCZI, I.M., KovÁCS, ZS. (2000): Vegyszeres állománykezelések hatása a búzafajták szemtermésének sikértartalmára, sikérterülésére és esésszámára. Növénytermelés 49(5): 487-499.

ZsomBIK, L., ERDÖS, Zs. (2014): Öszi búza (Triticum aestivum L.) genotípusok morfológiai paramétereinek változása vízhiányos körülmények között. In: Kis, Lívia Benita; Lukács Gábor; Nagy Barbara; Tóth Gergely (szerk.) Évfordulók-trendfordulók Festetics Imre születésének 250. évfordulója: LVI. Georgikon Napok. Keszthely, Magyarország: Pannon Egyetem Georgikon Mezőgazdaságtudományi Kar, 501-510.

ZsombIK, L., Seres, E. (2018): Nitrogénkezelések őszi búza (Triticum aestivum L.) agronómiai paramétereire gyakorolt hatása savanyú homoktalajon. Növénytermelés $67(2)$ : 87-108. 